\title{
Comparison of industrial-scale tubular photobioreactor to FRP (fiberglass reinforced plastic) panel photobioreactor on outdoor culture of Nannochloropsis oculata in the marine hatchery
}

\section{Denizel kuluçkahanede Nannochloropsis oculata dış ortam kültüründe endüstriyel ölçekli tübüler fotobiyoreaktör ile FRP (fiberglas ile güçlendirilmiş plastik) panel fotobiyoreaktörün karşılaştırılması}

\author{
Yaşar Durmaz $^{1 *}$ • Gökhun Çağatay Erbil2 \\ ${ }^{1}$ Aquaculture Department, Faculty of Fisheries, Ege University, 35100 Bornova, Izmir, Turkey \\ ${ }^{2}$ Aquaculture Department, Faculty of Fisheries, Kastamonu University, Kastamonu, Turkey
}

(D) $h$ ttps://orcid.org/0000-0002-1858-5882

(D) https://orcid.org/0000-0002-6704-5073

Durmaz, Y. \& Erbil, G.Ç. (2020). Comparison of industrial-scale tubular photobioreactor to FRP (fiberglass reinforced plastic) panel photobioreactor on outdoor culture of Nannochloropsis oculata in the marine hatchery. Ege Journal of Fisheries and Aquatic Sciences, 37(3), 303-308. DOI: 10.12714/egejfas.37.3.13

Abstract: Microalgal culture is a key procedure in marine fish hatcheries, but this activity is far from optimized and has several problems remain to be solved. Nannochloropsis oculata are important to live feed organisms, which are used to rear the larvae of marine finfish. N. oculata were cultivated in tubular PBR and FRP panel PBR in a greenhouse. Tubular PBR was reached $701.7 \times 10^{6}$ cells mL-1 as its maximum cell density and FRP panel PBR was reached $245 \times$ $10^{6}$ cells mL-1 as maximum. Also, estimated maximum dry weights of tubular and FRP panel PBRs were calculated as $3.249 \mathrm{~g} \mathrm{~L}^{-1}$ and $1.47 \mathrm{~g} \mathrm{~L}^{-1}$, respectively. Consequently, tubular PBR was showed that it is more efficient than FRP panel PBR in this study.

Keywords: Microalgae, Nannochloropsis oculata, hatchery, tubular photobioreactor, FRP panel photobioreactor, photobioreactor design

Öz: Mikroalg üretimi balık kuluçkahaneleri için kilit noktası olmakla birlikte hala optimizasyonu tamamlanmamış ve çözülmesi gereken problemlere sahiptir. Nannochloropsis oculata önemli bir canlı yem kaynağıdır ve deniz balıkları üretiminde larvaların beslenmesi amacıyla üretilmektedir. N. oculata, sera içerisinde tübüler ve FRP panel fotobiyoreaktörlerde üretilmiştir. Tübüler FBR $701,7 \times 10^{6}$ hücre $\mathrm{mL}^{-1}$ maksimum yoğunluğa ulaşırken, FRP panel FBR ise $245 \times 10^{6}$ hücre mL-1 maksimum yoğunluğa ulaşmışıı. Ayrıca, tübüler ve FRP panel FBR'ler için maksimum tahmini kuru ağırlıklar da sırasıyla $3,249 \mathrm{~g} \mathrm{~L}^{-1} \mathrm{ve}^{1,47 \mathrm{~g} \mathrm{~L}^{-1}}$ olarak hesaplanmıştır. Sonuç olarak, tübüler FBR'ün, FRP panel FBR'e göre daha verimli olduğu bu çalışma ile ortaya konulmuştur.

Anahtar kelimeler: Mikroalg, Nannochloropsis oculata, kuluçkahane, tübüler fotobiyoreaktör, FRP panel fotobiyoreaktör, fotobiyoreaktör tasarımı

\section{INTRODUCTION}

It is known that microalgae are known as a source of protein, amino acids, vitamins and various minerals, as well as polysaccharides, sterols and fatty acids (El-Sheekh et al. 2006). These organisms are an indispensable feed source for all growth stages of bivalves and for larvae of some crustaceans and fish species in aquaculture as used directly in larval tanks. They are consumed by zooplankton, which is then consumed by fish. In that aquatic feed chain, important nutrients from microalgae are transferred to higher trophic levels via intermediary zooplankton (Brown et. al., 1999; Vismara et. al., 2003). Although, microalgae are able to produce valuable biomolecules, which are alterable by nutrient composition, temperature, light intensity and age of the culture (Richmond, 1986; Renaud et al., 1995; Thompson et al., 1992).

Most of the microalgal biomass has been an appealing source for producing a wide range of highly valuable products, including polyunsaturated fatty acids (PUFA), carotenoids, phycobiliproteins, polysaccharides and phycotoxins. Although, the products from microalgae have been widely used as a highprotein supplement in human nutrition, aquaculture and nutraceutical purposes (Del-Campo et al., 2007). In most developed countries, high caloric foods are consumed widely. This leads to various health problems, e.g., obesity, heart diseases, diabetics. A balanced nutritional diet is needed for health and should contain valuable biomolecules such as vitamins, minerals, linoleic, linolenic and arachidonic acid as well as eicosapentaenoic acid (EPA, 20:5 omega-3) and docosahexaenoic acid (DHA, 22:6 omega-3) (Sathasivam et al. 2019).

The microalga Nannochloropsis oculata is an important species in aquaculture due to its nutritional value and cell size. It belongs to the class of Eustigmatophyceae, which includes species that contain a high amount of polyunsaturated fatty 
acids (PUFAs), especially eicosapentaenoic acid (EPA), arachidonic acid (ARA) and docosahexaenoic acid (DHA). These biomolecules have a great impact on the nutrition of marine organism, particularly growth and development of the larvae of fish, molluscs and crustaceans. (Otero et al., 1997, Brown et al., 1999). The nutritional value of microalgae is related to its biochemical cell composition particularly characteristics of fatty acid content (Sukenik et al., 1993; Durmaz et al., 2008). The cell composition of microalgae (Thompson et al., 1992) is alterable significantly through culture conditions, especially depending on temperature and light conditions (Richmond 2004; Durmaz et al., 2008).

Photobioreactors are bioreactors, which are utilizing the light as an energy source to produce phototrophic organisms such as microalgae. Since the beginning of microalgal cultivation, researchers have been investigating to find a more efficient way to produce these organisms. For this purpose, many photobioreactors are designed in different types and shapes. Open area tubular and flat plate photobioreactors are the most popular choices for high areal and volumetric productivity. From a commercial point of view, a closed photobioreactor (PBR) must have as many of the following characteristics as possible: high area productivity, high volumetric productivity, large volume, inexpensive to build and maintain, easy to control culture parameters and reliability (Olaizola, 2003). The culture of $N$. oculata is performed in closed photobioreactor (PBR) systems such as transparent polyethylene bags, fiberglass cylinders and flat panel reactors in hatcheries as feed for fish (Lubian et al., 2000; Lourenco et al., 2002).

In particular, low productivity and high production cost stand out as major hurdles of microalgae production in aquaculture hatcheries (Boeing, 2000; Durmaz, 2007; MullerFuege, 2013). In this case, PBRs should be optimized with respect to key design parameters for the cultivation of microalgae. Therefore, the goal of this study is comparing the performance of both systems (tubular \& flat plate PBRs) in semi-continuously mass microalgal cultivation of $N$. oculata using industrial-scale PBRs.

\section{MATERIAL AND METHODS}

\section{Microalgae}

Nannochloropsis oculata (Droop) (Hibberd, 1981 CCAP 849/1) used in this study was obtained from the Culture Collection of Algae and Protozoa (CCAP), Scotland. Starter cultures were maintained axenically in F/2 medium (Guillard and Ryther, 1962). When the inoculums reached a concentration between $10^{6}$ and $10^{7}$ cells $\mathrm{mL}^{-1}$, they were transferred to larger flat-bottom glass flasks $(10 \mathrm{~L})$, and then when the total volume was reached up to $200 \mathrm{~L}$ ( 20 flasks used for this purpose), cultures were inoculated to both PBRs.

\section{Experimental photobioreactor}

The experiments of this study were performed in a tubular PBR and a fiberglass reinforced plastic panel PBR (FRP; fiberglass reinforced plastic) which belongs to an aquaculture hatchery facility in Turkey (Akvatek Company), as shown in Figure 1 and Figure 2. Mainly, PBRs can be divided into two main parts; solar receiver and degasser-cooler tank. The degasser-cooler tank, which is made of double-walled polyester fiber tank was used for mixing, degassing and heat exchange of culture (Figure 1 and 2).

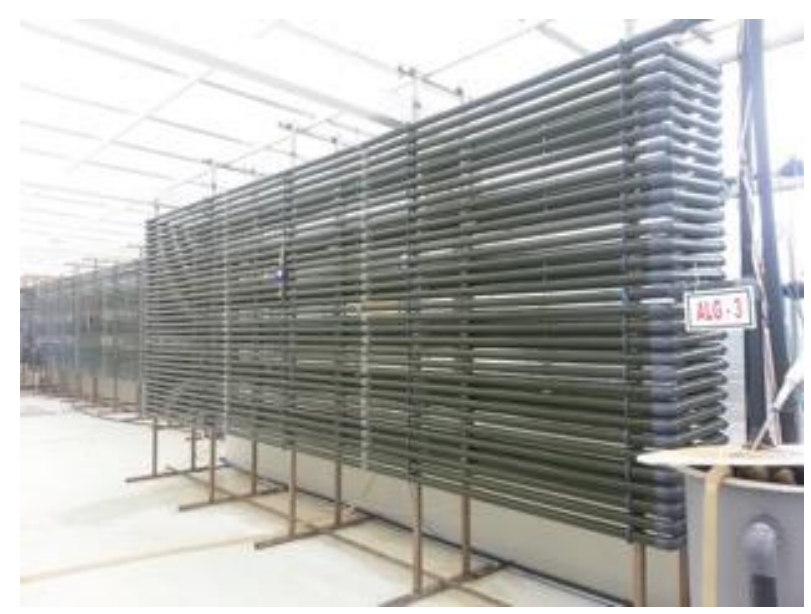

Figure 1. Tubular photobioreactor

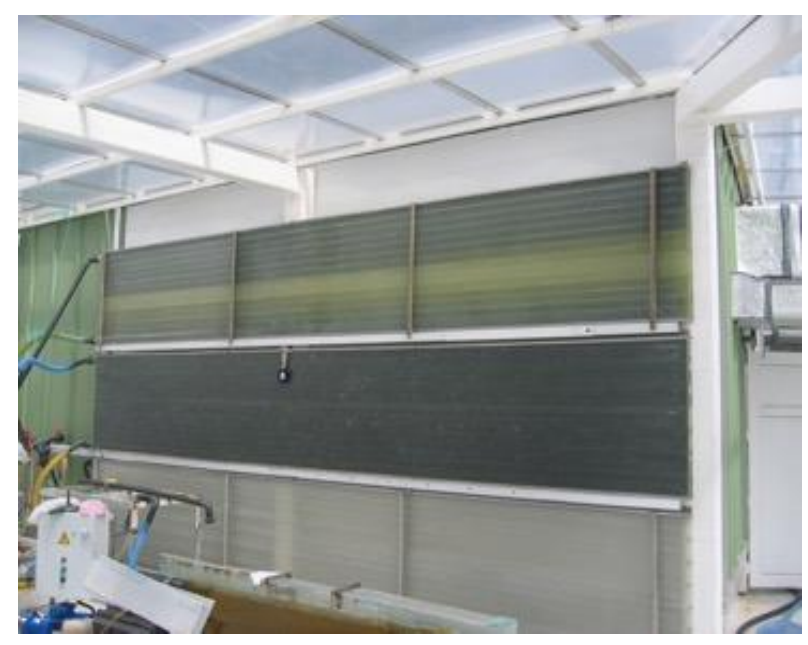

Figure 2. FRP panel photobioreactor

The solar receiver of the tubular PBR was made of transparent plexiglass consisted of $416 \mathrm{~m}$ total length (Figure 3). The internal diameter of the tubes was $4.6 \mathrm{~cm}$ and has 0.2 $\mathrm{cm}$ wall thickness. The solar receiver consists of two lines and each set of the tubular PBR has $6 \mathrm{~m}$ in length, $0.5 \mathrm{~m}$ in width and $1.6 \mathrm{~m}$ in height. The effective surface area of both lines of tubular PBR is $41.6 \mathrm{~m}^{2}$ and the solar receiver's volume was 690 liters. The degasser-cooler tank of the tubular system has 110 liters volume and finally, the total volume of the tubular PBR system reaches 800 liters. 


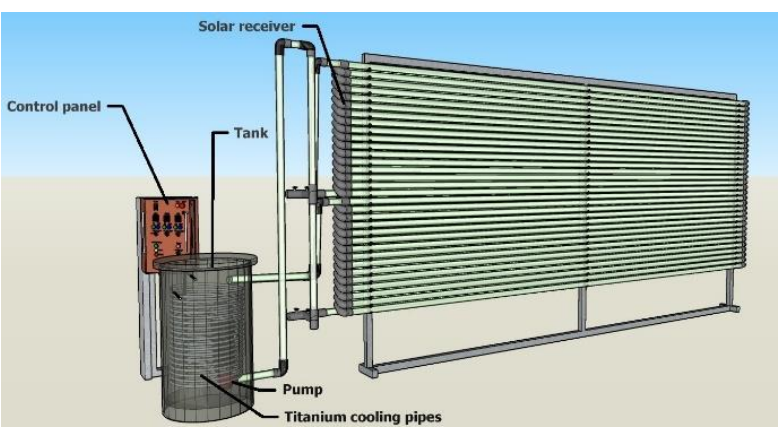

Figure 3. Illustration of the tubular photobioreactor

The solar receiver of the FRP panel PBR was made of fiberglass reinforced plastic. Two-piece of FRP panel solar receivers were used in this PBR system (Figure 4). Both have $9.5 \mathrm{~m}$ in length and $1 \mathrm{~m}$ in height, has $4 \mathrm{~cm}$ in depth. The total surface area of the solar receiver is $38 \mathrm{~m}^{2} .800$ liters of total volume of the FRP panel PBR including 40 liters of the degasser-cooler tank.

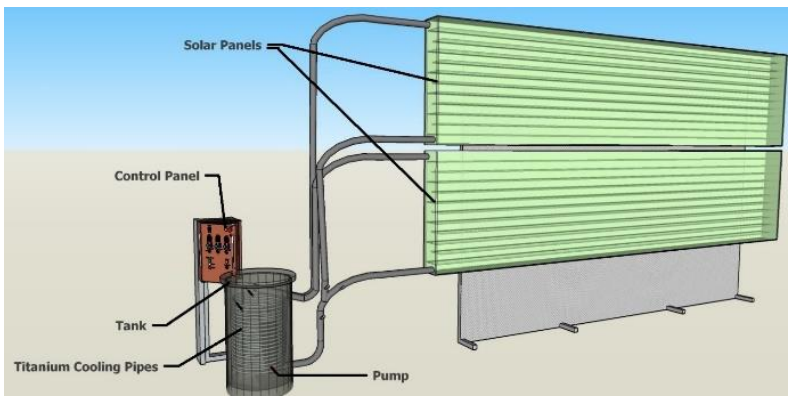

Figure 4. Illustration of FRP panel photobioreactor

The culture temperature was controlled through an internal heat exchanger that was made up of titanium tubes placed in the degasser-cooler tank. $100 \mathrm{~L}$ of seawater per hour (generally $18^{\circ} \mathrm{C}$ ) was used as cooling water. The microalgal culture was circulated as velocity of $0.6 \mathrm{~m} \mathrm{~s}^{-1}$ using a centrifugal pump located between the degasser-cooler tank and the solar receiver. Temperature and $\mathrm{pH}$ were measured at several positions along with the tube and degasser tank using Seko Kontrol PR40 pH/redox and conductivity meter (Italy). Culture $\mathrm{pH}$ was controlled by on-demand injection of pure industrial grade $\mathrm{CO}_{2}$ gas at $5 \mathrm{~L} \mathrm{~min}^{-1}$.

\section{Culture conditions of photobioreactors}

Advanced mass culture of microalgae requires a closed system because the microalgae must be grown under contaminant-free conditions. However, it is not possible to completely sterilize PBRs. In this study, PBRs were disinfected by using sodium hypochlorite overnight and neutralized with sodium thiosulfate for 2 hours. In addition, marine water used in both systems was sterilized by passing through a $0.02 \mu \mathrm{m}$ filtration system.
PBR systems were illuminated by solar radiation and no artificial illumination was used at nights. Sunrise and sundown were observed around 05.30 and 19.30 , respectively. The mean duration of irradiation was $14 \mathrm{~h}$ per a day. Mean temperature was recorded as $26-28{ }^{\circ} \mathrm{C}$ at daytimes and $18-20$ ${ }^{\circ} \mathrm{C}$ at nights.

Culture medium (F/2 medium (Guillard and Ryther, 1962)) was added daily $(1 \mathrm{~mL} / \mathrm{L})$ and cultures were maintained at 35 $\mathrm{g} \mathrm{L}^{-1}$ salinity and $24 \pm 1^{\circ} \mathrm{C}$ temperature.

\section{Analytical methods}

Cell density was measured via Improved Neubauer hemocytometer at three times a day (08:00 a.m., 12:00 p.m. and 18:00 p.m) and at the same time, contamination was checked daily through visual observation. Growth rates $(\mu)$ were calculated with this equation.

$$
\mu=\frac{\ln \left(N_{t}\right)-\ln \left(N_{0}\right)}{t-t_{0}}
$$

Where $\mathrm{N}_{\mathrm{t}}$ is biomass at the time $(\mathrm{t})$ and $\mathrm{N}_{0}$ is the beginning biomass at the time $t_{0}$.

The culture was illuminated through sun light at the maksimum irradiance level of $300 \mu \mathrm{mol} \mathrm{m} \mathrm{m}^{-2} \mathrm{~s}^{-1}$ (Li-Core 195) at the surface of the photobioreactors.

\section{RESULTS}

In both PBR systems, no contamination by protozoa or other microalgae species was observed. The tubular PBR's and FRP panel PBR's initial cell densities were arranged as $15.0 \times 10^{6}$ cells $\mathrm{mL}^{-1}$ (Figure 5). Tubular PBR was reached to maximum cell density at $14^{\text {th }}$ day as $701.7 \times 10^{6}$ cells $\mathrm{mL}^{-1}$ while FRP panel PBR was reached to maximum cell density at $23^{\text {rd }}$ day and recorded as $245 \times 10^{6}$ cells $\mathrm{mL}^{-1}$. The lag phase was observed in the first 2 days for both PBRs. After the first 2 days, the cell density of $N$. oculata at tubular PBR was increased rapidly from $35.3 \times 10^{6}$ cells $\mathrm{mL}^{-1}$ and was reached to $701.7 \mathrm{x}$ $10^{6}$ cells $\mathrm{mL}^{-1}$ at the day 14 without any apparent lag phase. However, the exponential phase of the PFR panel PBR continued relatively slowly until the $17^{\text {th }}$ day and reached $205 \mathrm{x}$ $10^{6}$ cells $\mathrm{mL}^{-1}$.

Maximum specific growth rates of tubular PBR and FRP panel PBR were recorded at the day 5 as 0.53 and 0.39 , respectively. Estimated dry weights were calculated according to data of previous studies (FAO, 1996; Zou and Richmond, 1999). The maximum estimated dry weights of tubular PBR and FRP panel PBR were calculated as $3.249 \mathrm{~g} \mathrm{~L}^{-1}$ and $1.47 \mathrm{~g}$ $\mathrm{L}^{-1}$, respectively. When compare maximum dry weights of PBRs, the tubular PBR system was reached to 2.21-fold of FRP panel system's dry weight (Figure 6). Mean estimated dry weights of both bioreactors for 32 days long experiments, were calculated as 2.091 and $0.806 \mathrm{~g} \mathrm{~L}^{-1}$ for tubular and FRP panel PBRs, respectively. 




Figure 5. Cell densities of both systems

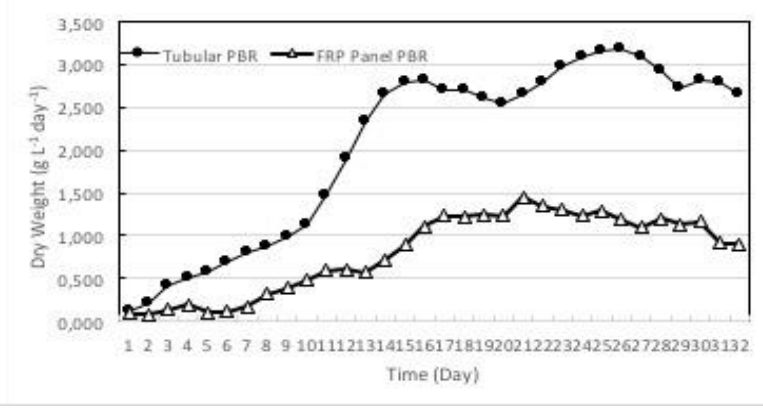

Figure 6. Estimated dry weights of both systems

\section{DISCUSSIONS}

The primary objective of producing phototrophic organisms is to provide a continuous culture with cell density. Strong irradiance often results in photodamage on several microalgae species but, if cell population density is too low even lower irradiances may cause the same effect (Qiang and Richmond, 1994). Light is an important parameter, especially in algal cultures. The angle at which the photobioreactor receives the light is important, in fact, the surface area of the material plays a significant role in the efficiency to get enough light for the algal culture. In this study, the greenhouse was possibly reduced the light intensity at the beginning and consequently, no photodamage was observed. It is important for the reactor to take sunlight in the most efficient way.

The maximum cell number of the tubular PBR system was more than 2 fold higher than FRP panel PBR's. In another study, bag cultivation of $N$. oculata was conducted $(50 \mathrm{~L})$ to test the effect of $\mathrm{N}$ sources $\left(\mathrm{NO}_{3}{ }_{3}\right.$ and $\left.\mathrm{NH}_{4}^{+}\right)$and maximum cell number was given as $5.2 \pm 0.3 \times 10^{7}$ cells $\mathrm{mL}^{-1}$ and $4.9 \pm 0.1$ $x 10^{7}$ cells $\mathrm{mL}^{-1}$, respectively (Durmaz, 2007). The harvest cell densities of $N$. oculata in the medium supplemented with 1.76 mmol N L-1 were $5.28 \times 10^{7}$ cells $\mathrm{mL}^{-1}$ (Huang et al., 2013). Low and Toledo (2015) reported that $80 \mathrm{~L}$ culture bags of $N$. oculata were harvested with an approximate concentration of $4.55 \mathrm{x}$
$10^{6}$ cells $\mathrm{mL}^{-1}$. It is obvious that in this study, cell densities of both PBR systems higher than bag culture methods.

The total biomass yield was considerably higher than algae concentrations in open raceway ponds, which typically ranged between 0.1 and $0.5 \mathrm{~g} \mathrm{~L}^{-1}$ (Kumar et al., 2015; Zhu, 2015), but can reach up to $1.4 \mathrm{~g} \mathrm{~L}^{-1}$ (Ashokkumar et al., 2014; Ketheesan and Nirmalakhandan, 2012). This biomass yield is comparable to average biomass concentrations achieved in other PBRs such as tubular and flat plate PBRs. Higher yields were obtained as varied between 2.07-4.3 $\mathrm{g} \mathrm{L}^{-1}$ for Nannochloropsis atomus species on horizontal PBR which operated over 165day (Dogaris et al., 2015). In another study, it is reported that productivity of continuous culture as 2.02 and $3.03 \mathrm{~g} \mathrm{~L}^{-1} \mathrm{day}^{-1}$ at helical tubular PBR (Briassoulis et al., 2010) in summer with combined light conditions. That result shows that helical tubular PBR's performance was better than our FRP panel PBR's, but similar to tubular PBR's performance. It is also reported as 1.10 and $1.20 \mathrm{~g} \mathrm{~L}^{-1}$. day-1 productivity for fed-batch culture at artificial light conditions (Xu et al., 2004). The maximum productivity of Nannochloropsis sp. in a flat-plate PBR reported as $0.51 \mathrm{~g} \mathrm{~L}^{-1}$ $\mathrm{d}^{-1}$ (Hulatt et al., 2017). Tubular PBR system was yielded 3.249 $\mathrm{g} \mathrm{L}^{-1}$ maximum dry weight in this study. While the yield of tubular PBR's is higher or comparable with mentioned studies, the FRP panel PBR's yield significantly lower than most of these results. Culture intensity is associated with culture depth and light intensity. This relation must be considered linearly. In this study, $4.6 \mathrm{~cm}$ diameter tubes were used with solar irradiation. Although the FRP panel PBR system has a $4 \mathrm{~cm}$ light path length, the panel system lines are in shadowing each other. This may lead to a decrease in the light efficiency ratio. The length of the light path has been taken into account in order to optimize the light intensity.

The algae biomass is affected by many parameters including light intensity, the surface area and material of the system used, and the path taken by the light in the water column.

\section{CONCLUSION}

Microalgal biotechnology takes more attention day after day by different industries. Along with its use in aquaculture, naturally produced valuable biomolecules such as fatty acids, vitamins and pigments are used in different fields more often than ever. For that reason, the capacity and efficiency of microalgae production need improvement. Although open systems like ponds let us produce a couple of microalgae species successfully, these systems limit the production of many sensitive species because of contamination risk and/or uncontrolled conditions. Also, those systems need too much space because of their low production efficiency. This leads producers to work with closed systems that allow reliable and sustainable production.

PBR systems have a significant effect on the growth rate of $N$. oculata cultivation. In tubular PBRs, this species can be 
easily grown and possible to obtain maximum biomass under solar illumination.

Our results indicate that this design offers the advantage of a high surface to volume ratio, easy controlling of temperature and carbon dioxide transfer, while occupying a small ground area. In addition, totally controlled lights may ensure optimum illumination constantly to provide persistence of production, which is not possible for solar illuminated systems. However, artificial lightning causes extra costs for production. This design is used to be able to grow algae throughout the year, especially in hatchery production seasons. By doing so, the success of

\section{REFERENCES}

Ashokkumar, V., Agila, E., Sivakumar, P., Salam, Z., Rengasamy, R. \& Ani, F. N. (2014). Optimization and characterization of biodiesel production from microalgae Botryococcus grown at semi-continuous system. Energy Conversion and Management, 88, 936-946.

DOI: 10.1016/j.enconman.2014.09.019

Boeing, P. (2000). Larval feed alternatives. Global Aquaculture Advocate 3 (1): $48-50$

Briassoulis, D., Panagakis, P., Chionidis, M., Tzenos, D., Lalos, A., Tsinos, C. \& Jacobsen, A. (2010). An experimental helical-tubular photobioreactor for continuous production of Nannochloropsis sp. Bioresource Technology, 101(17), 6768-6777. DOI: 10.1016/j.biortech.2010.03.103

Brown, M.R., Mular, M., Miller, I., Farmer, C. \& Trenerry, C. (1999). The vitamin content of microalgae used in aquaculture. Journal of Applied Phycology, 11(3), 247-255. DOI: 10.1023/A:1008075903578

Del Campo, J. A., García-González, M. \& Guerrero, M.G. (2007). Outdoor cultivation of microalgae for carotenoid production: current state and perspectives. Applied microbiology and biotechnology, 74(6), 1163-1174. DOI: 10.1007/s00253-007-0844-9

Dogaris, I., Welch, M., Meiser, A., Walmsley, L. \& Philippidis, G. (2015). A novel horizontal photobioreactor for high-density cultivation of microalgae. Bioresource Technology, 198, 316-324. DOI: 10.1016/j.biortech.2015.09.030

Durmaz, Y. (2007). Vitamin E (a-tocopherol) production by the marine microalgae Nannochloropsis oculata (Eustigmatophyceae) in nitrogen limitation. Aquaculture, 272(1), 717-722. DOI: 10.1016/j.aquaculture.2007.07.213

Durmaz, Y., Donato, M., Monteiro, M., Gouveia, L., Nunes, M. L., Gama Pereira, T., Gokpinar, S. \& Bandarra, N. M. (2008). Effect of Temperature on Growth and Biochemical Composition (Sterols, a-tocopherol, Carotenoids, Fatty Acid Profiles) of the Microalga, Isochrysis galbana. Israeli Journal of Aquaculture - Bamidgeh, 60(3), 188-195.

El-Sheekh, M. M., Osman, M. E., Dyab, M. A. \& Amer, M.S., (2006). Production and characterization of antimicrobial active substance from the cyanobacterium Nostoc muscorum. Environmental toxicology and pharmacology, 21(1), 42-50.

FAO, (1996). Manual on the Production and Use of Live Food for Aquaculture. FAO Fisheries Technical Paper No. 361. Rome.

Guillard, R. R. \& Ryther, J.H. (1962). Studies of marine planktonic diatoms: I. Cyclotella Nana Hustedt, and Detonula Confervacea (CLEVE) Gran. Canadian Journal of Microbiology, 8(2), 229-239. DOI: 10.1139/m62-029

Hibberd, D.J., (1981). Notes on the taxonomy and nomenclature of the algal classes Eustigmatophyceae and Tribophyceae (synonym Xanthophyceae). Botanical Journal of Linnean Society, 82(2), 93-119. DOI: 10.1111/j.1095-8339.1981.tb00954.x

Huang, X., Huang, Z., Wen, W. \& Yan, J. (2013). Effects of nitrogen supplementation of the culture medium on the growth, total lipid content and fatty acid profiles of three microalgae (Tetraselmis subcordiformis, breeding alternative fish species in mariculture operations may be increased.

\section{ACKNOWLEDGEMENTS}

We hereby declare that both authors worked together in this work and participated in data analyses, discussion of results, writing and revising the manuscript. No conflicts, informed consent, human or animal rights applicable. All the authors agree to their authorship and agree to the submission of the manuscript for peer review.

Nannochloropsis oculata and Pavlova viridis). Journal of Applied Phycology, Volume 25, Issue 1, 129-137.

Hulatt, C.J., Wijffels, R.H., Bolla, S., \& Kiron, V. (2017). Production of fatty acids and protein by Nannochloropsis in flat-plate photobioreactors. PLOS ONE, 12(1), e0170440. DOI: 10.1371/journal.pone.0170440

Ketheesan, B. \& Nirmalakhandan, N. (2012). Feasibility of microalgal cultivation in a pilot-scale airlift-driven raceway reactor. Bioresource Technology, 108:196-202. DOI: 10.1016/j.biortech.2011.12.146

Kumar, K. S., Dahms, H. U., Won, E. J., Lee, J. S. \& Shin, K. H. (2015). Microalgae-A promising tool for heavy metal remediation. Ecotoxicology and Environmental Safety, 113, 329-352. DOI: 10.1016/j.ecoenv.2014.12.019

Lourenco, S., Barbarino, E., Mancini-Filho, J., Schinke, K. \& Aidar, E. (2002). Effect of different nitrojen sources on the growth and biochemical profile of 10 marine microalgae in batch culture: An evaluation for aquaculture, Phycologia 12, 249-255.

Low, C. \& Toledo, M.I. (2015). Assessment of the shelf-life of Nannochloropsis oculata flocculates stored at different temperatures. Latin American Journal of Aquatic Research, 43(2), 315-321.

Lubián, L.M., Montero, O., Moreno-Garrido, I., Huertas, I. E., Sobrino, C., González-del Valle, M. \& Parés, G. (2000). Nannochloropsis (Eustigmatophyceae) as source of commercially valuable pigments. Journal of Applied Phycology, 12(3-5), 249-255.

Muller-Feuga A. (2013). Microalgae for aquaculture: the current global situation and future trends. In: Richmond A, Hu Q. Eds., Handbook of microalgal culture: Applied phycology and biotechnology, Wiley Blackwell, Chichester, 613-627. DOI: 10.1002/9781118567166.ch33

Olaizola, M. (2003). Commercial development of microalgal biotechnology: from the test tube to the marketplace. Biomolecular Engineering, 20(4), 459-466.

Otero, A., García, D. \& Fábregas, J. (1997). Factors controlling eicosapentaenoic acid production in semicontinuous cultures of marine microalgae. Journal of Applied Phycology, 9(5), 465-469. DOI: 10.1023/A:1007930804367

Qiang, Hu., \& Richmond, A. (1994). Mikroalgae Optimizing the population density in Isochrysis galbana grown outdoors in a glass column photobioreactor. Journal of Applied Phycology, 6(4), 391-396. DOI: 10.1007/BF02182155

Renaud, S. M., Zhou, H.C., Parry, D.L., Thinh, L.V. \& Woo, K. C. (1995). Effect of temperature on the growth, total lipid content and fatty acid composition of recently isolated tropical microalgae Isochrysis sp., Nitzschia closterium, Nitzschia paleacea, and commercial species Isochrysis sp. (clone T. ISO). Journal of Applied Phycology, 7(6), 595-602. DOI: 10.1007/BF00003948

Richmond A. (1986). Cell response to environmental factors. pp. 69-99. In: A. Richmond (ed.). CRC Handbook of Microalgal Mass Culture. CRC Press, Boca Raton, FL. 
Richmond, A., (2004). Principles for attaining maximal microalgal productivity in photobioreactors: an overview. Hydrobiologia, 512(1-3), 33-37. DOI: 10.1023/B:HYDR.0000020365.06145.36

Sathasivam, R., Radhakrishnan, R., Hashem, A. \& Abd_Allah, E. F. (2019). Microalgae metabolites: A rich source for food and medicine. Saudi journal of biological sciences, 26(4), 709-722. DOI: 10.1016/j.sjbs.2017.11.003

Sukenik, A., Zmora, O. \& Carmeli, Y. (1993). Biochemical quality of marine unicellular algae with special emphasis on lipid composition. II. Nannochloropsis sp. Aquaculture, 117(3-4), 313-326. DOI: 10.1016/0044-8486(93)90328-V

Thompson, P. A., Guo, M. X. \& Harrison, P.J. (1992). Effects of variation in temperature. I. On the biochemical composition of eight species of marine phytoplankton. Journal of Phycology, 28(4), 481-488.

DOI: $10.1111 / j .0022-3646.1992 .00481 . x$
Vismara, R., Vestri, S., Kusmic, C., Barsanti, L. \& Gualtieri, P. (2003). Natural vitamin $E$ enrichment of Artemia salina fed freshwater and marine microalgae. Journal of Applied Phycology, 15(1), 75-80. DOI: 10.1023/A:1022942705496

Xu, F., Hu, H. H., Cong, W., Cai, Z. L. \& Ouyang, F. (2004). Growth characteristics and eicosapentaenoic acid production by Nannochloropsis sp. in mixotrophic conditions. Biotechnology Letters, 26(1), 51-53.

DOI: 10.1023/B:BILE.0000009460.81267.cC

Zhu, L. (2015). Biorefinery as a promising approach to promote microalgae industry: An innovative framework. Renewable Sustainable Energy Review, 41, 1376-1384. DOI: 10.1016/j.rser.2014.09.040

Zou, N. \& Richmond, A. (1999). Effect of light-path length in outdoor fiat plate reactors on output rate of cell mass and of EPA in Nannochloropsis sp. In Progress in Industrial Microbiology, Vol. 35, 351-356. DOI: 10.1016/S0079-6352(99)80127-1 